TITLE:

\title{
ON THE INTERSPECIFIC ASSOCIATION OF A SNAPPING SHRIMP AND GOBIOID FISHES
}

$\operatorname{AUTHOR}(\mathrm{S})$ :

Harada, Eiji

CITATION:

Harada, Eiji. ON THE INTERSPECIFIC ASSOCIATION OF A SNAPPING SHRIMP AND GOBIOID FISHES. PUBLICATIONS OF THE SETO MARINE BIOLOGICAL LABORATORY 1969, 16(5): 315 334

ISSUE DATE:

1969-01-31

URL:

http://hdl.handle.net/2433/175555

RIGHT: 


\title{
ON THE INTERSPECIFIC ASSOCIATION OF A SNAPPING SHRIMP AND GOBIOID FISHES ${ }^{1)}$
}

\author{
EIJI HARADA \\ Biological Laboratory, Yoshida College, Kyoto University
}

With 10 Text-figures and 2 Tables

For some years the presence of two kinds of fish inhabiting burrows on the sandy bottom has been noticed by diving observation in the shallow waters of Ezura and Rinkai areas in Tanabe Bay. Although accurate identification of them had to wait until some specimens were obtained recently, one of them was determined undoubtedly to be Vireosa hanae JoRDAN et STARKS and the other of dominant occurrence was regarded to be Amblyeleotris japonicus TAKAGI through diving observations and examination of a specimen stranded after the hit of cold weather by Mr. Ch. ARAGA of the Seto Marine Biological Laboratory (Araga and TAnase, 1968). These fishes are extremely quick in withdrawing into burrows whenever divers come close to them, at nearest 1 to 2 metres, and had been believed to be the hosts of burrows.

In summer 1966, I happened to witness that there were another inhabitants of burrows beside these fishes. They were readily distinguished to be the snapping shrimp, coloured with stripes of white and dark purple, and, moreover, appeared to be the genuine hosts of burrows for their behaviour. They were always observed to come out behind gobioid fishes, pushing sand out of burrows, and seemed to be very timid and prepared for quick retreat at any time when some moving objects approached to them. The fact that they scarcely step out when gobioid fishes are hanging about the entrance of burrows has presumably caused them to escape from divers' eyes.

In the following summer, I had succeeded in collecting some specimens of the snapping shrimp in question to render for identification by Mr. Y. MrYA, and in summer 1968 couples of snapping shrimp and gobioid fish were successfully captured alive and were brought back to Kyoto to enable closer observation of their behaviour and experimental treatment in an aquarium. The snapping shrimp was ascribed to a new species of the brevirostris group of the genus Alpheus by Mr. Y. MrYA (his letter of May 22, 1968) and has just been described under the specific name of Alpheus bellulus in the preceding article (Mrya and Mryake, 1968). At the same time, the gobioid

1) Contributions from the Seto Marine Biological Laboratory, No. 500.

Publ. Seto Mar. Biol. Lab., XVI (5), 315-334, 1969. (Article 24) 
fish of dominant occurrence has been ascertained to be Amblyeleotris japonicus TAKagI.

Various gobioid fishes are known to live in the burrow of respective snapping shrimp, and their relationships, as well as those between gobioid fishes and ghost shrimps, are customarily referred to in text-books as an example of commensalism (MACGinitie and MacGinitie, 1949; Yonge, 1949; Nicol, 1960; Schöne, 1961; etc.). Partnerships of different combination of species between snapping shrimp and gobioid fish have been further reported by MACNAE (1957) from Port Elizabeth, Luther (1958) from the Red Sea, Herald (1961) on Indo-West Pacific species and Macnae and Kalk (1962) from Moçambique, of whom LuTHER gives the most detailed description.

The present case of the snapping shrimp sharing the burrow with gobioid fishes affords undoubtedly another example of the association of snapping shrimp and gobioid fish. While behaviours and interrelations of the partner animals concerned coincide in many respects with those described by these authors cited above, the evidences have been also obtained, that have not been mentioned and that would account for the nature of the relationships. The observations presented in this paper were chiefly carried out underwater in the summers of 1967 and 1968, and additional observations were also made underwater in December 1967 and in an aquarium in August 1968 .

I would like to express my sincere thanks to Mr. Ch. Araga and Mr. Y. Mrya for affording me of their records of observation and generously allowing me to cite them in the present paper. Professor H. Utinomi, Dr. T. Tokioka and Mr. Y. Miya have kindly informed me of literatures, to whom I am indebted. My thanks are also due to Miss Akemi Masuda for her assistance in photography. Dr. R. Okuno has given me much critical discussions, to whom I am most grateful.

\section{Habitat and Distribution}

The burrows of the snapping shrimp, Alpheus bellulus Mrya and Mryake, are found in comparatively restricted areas of the bottom surrounding rocky reefs at depths from 2 to 7 metres, particularly abundantly at about 5 metres deep below the low water level. The substratum of these areas is characterized generally by an exceeding amount of stones and coral debris buried in fine sand which is blackened usually at a depth of 5 to $10 \mathrm{~cm}$ from the surface, if it appears to be clean on the bottom surface. Occasionally Zostera nana and Halophila ovalis are growing over the bottom, but in this area, too, stones and dead shells are buried somewhat deeper in the substratum.

The burrows of the snapping shrimp are invariably constructed beneath and among these hard objects which are apparently utilized as supportings of burrows. Consequently, in general, on the bottom with a larger amount of stones and coral fragments the burrows are lying shallower beneath the surface horizontally, while on the bottom of much sandy substratum with plant vegetation they plunge steeply into the substratum. Even if the substratum surrounding the entrance of a burrow appears to be fine sand, the burrow is usually found leading under stones when 


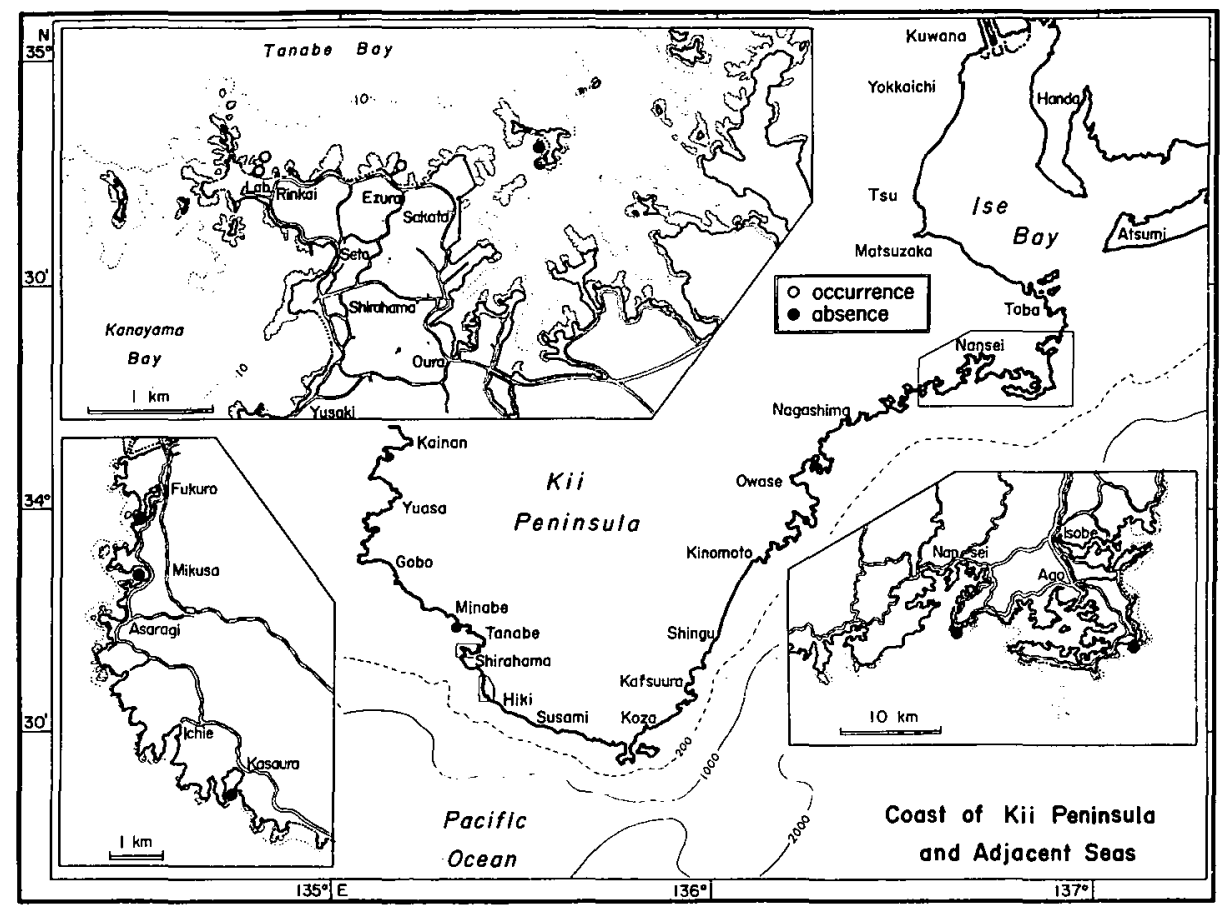

Fig. 1. Map showing sites visited for observation and localities of occurrence of Alpheus bellulus and Amblyeleotris japonicus.

it is traced by digging up the bottom. Such favourable conditions of the substratum are prevailing in and restricted to the areas fringing rocky reefs. These features of the habitat and burrow resemble those of Alpheus djiboutensis in the Red Sea, living together with Cryptocentrus octofasciatus and unidentified species of the same genus, on which LuTHER (1958) describes: "Zwischen solchen ,"Tafelbergen" liegen kleine mit Sand gefüllte Täler und grössere Sandflächen in einer Tiefe von etwa 2-8 mtr." and "Er gräbt in dem Sandboden der Korallentälchen mindestens 20-30 cm tiefe Höhlen, deren Eingang meist durch einen flachen Stein oder ein Korallenbruchstück gestützt ist."

The substratum surrounding the burrow collapses easily and it is hardly possible to follow to its extremities. When water is forced into a burrow from its entrance, streams of water jetting out from small openings are seen at places on the neighbouring bottom, that may be an indication of branching of the burrow. On a most successful occasion the burrow was traced underwater along its main tunnel over about $40 \mathrm{~cm}$ in length among and beneath stones and coral fragments and was there lost away. In no case when the bottom encircling the entrance of a burrow is excavated down to a depth of about $30 \mathrm{~cm}$ and to an area of about 1 metre in diameter are any snapping shrimps and gobioid fishes found lurking in or creeping out of the substratum. 


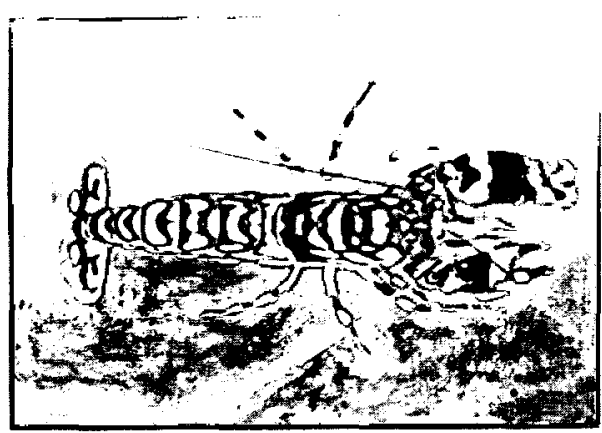

Fig. 2. A specimen of Alpheus bellulus, female, collected at Rinkai on 22 August, 1968. Natural size.

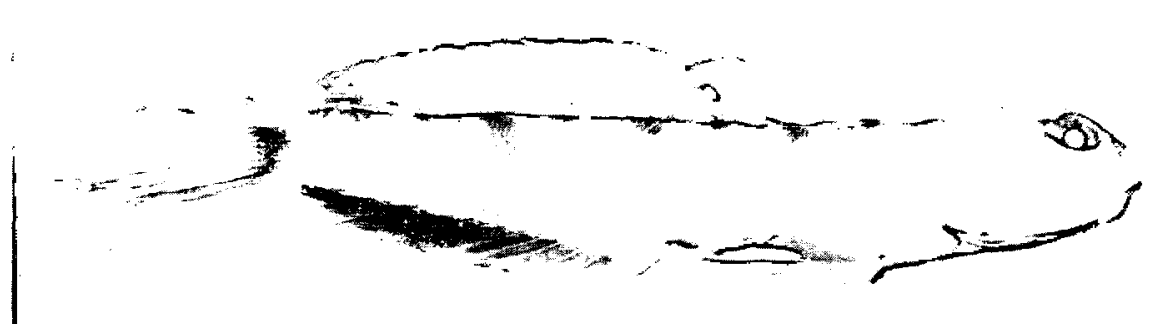

Fig. 3. A specimen of Amblyeleotris japonicus, collected at Ezura on 5 August, 1968. Natural size.

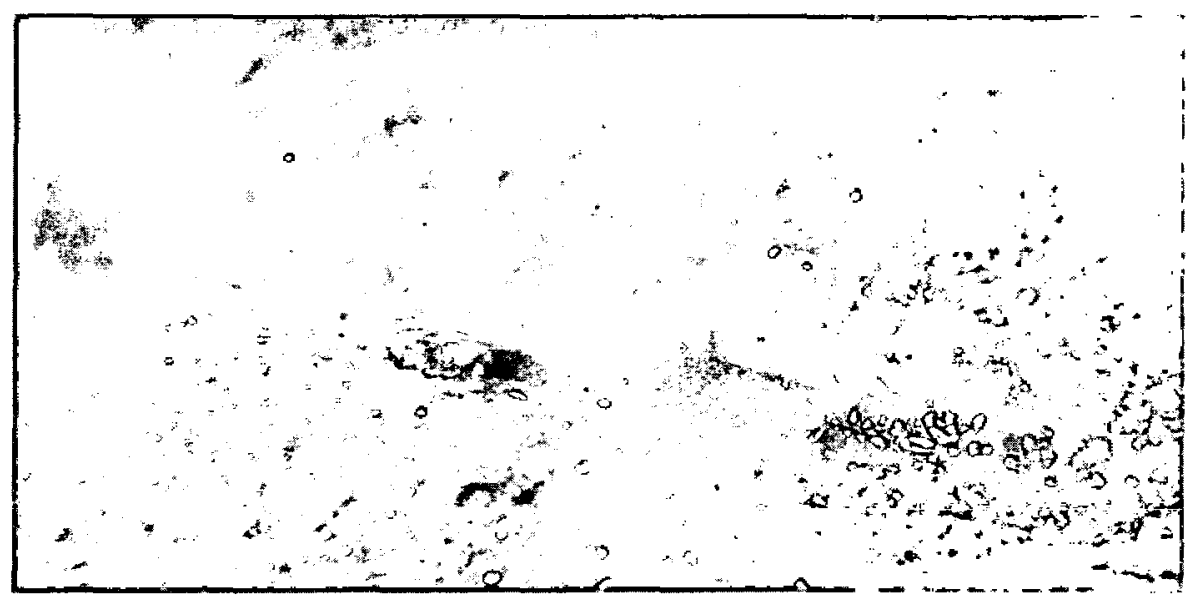

Fig. 4. Underwater photograph of Alpheus bellulus pushing the sand out of the burrow (on the left) and Amblyeleotis japonicus posting near the entrance. It is a very rare case that the shrimp walks out beyond the fish as is seen here. 
The burrow a captive shrimp had made in an aquarium was bending in all directions. On repairing, the shrimp often excavated branches of tunnel and finally opens a new entrance, whereby the original entrance was deserted.

In the discussion of ecology of Hawaiian snapping shrimps BANNER (1953) discriminated five types of habitats for shallow water species. According to his classification, the present species may be attributable to the third category of living "in sandy or muddy portions of the inner reef and of bays, where they hide about the bases of rocks and partially buried objects." Similar burrowing habits are referred to by MacGinitie and MagGinitie (1949, p. 278) for Alpheus dentipes and A. bellimanus.

Diving observations to confirm their habitats have been made at various localities along the coast of Kii Peninsula (Fig. 1). It is, however, unsuccessful so far to find Alpheus bellulus, and accordingly the partner gobioid fishes, at any places except Ezura and Rinkai in Tanabe Bay, perhaps due partly to lack of suitable substratum and partly to scarcity of diving localities. According to Mr. Ch. Araga, on the other hand, the snapping shrimp was also found dwelling together with Amblyeleotris japonicus in the burrow on a bottom of similar type in fringing areas of rocky reefs near Ushibuka of the Amakusa Islands, Kyushu, in September 1967. A record of collection from Kaminose in Kagoshima Bay, Kyushu, appears in the preceding paper of MrYA and MiYake (1968). Alpheus bellulus seems apparently to have a wide range of distribution in shallow waters of south-west Japan.

It is not shown in the original description of Amblyeleotris japonicus by TAKAGI (1957), the specimens of which were collected in tide-pools in Kagoshima Bay, whether this gobioid fish is living in the burrow of snapping shrimp. Considering from this habitat of the fish in Kagoshima Bay, although it is not absolutely impossible to find in a huge tide-pool the bottom of similar type to that inhabited by Alpheus bellulus in the water of the present study, it seems rather improbable that they live in the burrow of this snapping shrimp, should the different species of snapping shrimp be associated. The case needs further observation.

\section{Associated Occurrence of the Snapping Shrimp and Gobioid Fishes}

In the areas of Ezura and Rinkai, described as the habitats for Alpheus bellulus, it is the sole species of snapping shrimp burrowing on the bottom and living together with gobioid fishes. These gobioid fishes so far confirmed are Amblyeleotris japonicus TAKagi, Vireosa hanae Jordan et Starks, Eleotriodes helsdingeni Bleeker and an other unidentified gobioid fish, all belonging to the family Eleotridae.

Amblyeleotris japonicus has predominant population among them. They are usually seen resting on the bottom in close vicinity to the entrance of the burrow of the snapping shrimp, when, as will be described later, snapping shrimps are actively engaged in clearing burrows. Vireosa hanae is mostly found hovering in pairs about a half metre above the entrance. Eleotriodes helsdingeni, which is very rare and whose identification should accurately be done on some specimens to be collected, is also 
swimming above the bottom and darts into a burrow when a diver comes near to it. In the case of this fish, however, there is a little doubt whether the burrow is of the snapping shrimp or of its own. The last gobioid fish of uncertain identification is very much like Amblyeleotris japonicus in size, colour and behaviour, and is rarely found and scarcely allows closer observation.

On the bottom where the most abundant population of Alpheus bellulus is found, entrances of its burrows distribute less than 1 metre apart from one another. A shallow depression on the surface, being marked as snapping shrimps push sand away from their burrows, is usually extending straight from the entrance over some 20 to $50 \mathrm{~cm}$. These depressions never meet one another, indicating that snapping shrimps of different burrows seldom, if ever, come across one another on the bottom, at least during the time when they are clearing their burrows in daytime.

Snapping shrimps are not always witnessed for each burrow underwater. Burrows presently inhabited by the snapping shrimp can be easily discerned by a depression mentioned above and conditions of the surface by the entrance. Although there are many cases in which only gobioid fishes are seen at the entrance, this can never be taken as a sign of the absence of the snapping shrimp. On the contrary, in no case are seen only snapping shrimps occupying a burrow, not accompanied by at least one Amblyeleotris japonicus.

It is not possible to know exactly how many snapping shrimps and gobioid fishes are inhabiting the same burrow. As far as the cases in which both snapping shrimp and gobioid fish were observed dwelling in a burrow are concerned, the cases in which one Alpheus bellulus and one Amblyeleotris japonicus occurred in partnership attain more than three-fourths of all. Frequently two snapping shrimps are seen coming out of the same burrow. In these cases, one or two Amblyeleotris japonicus are resting near the entrance. It is also not uncommon that one snapping shrimp is sharing a burrow with two Amblyeleotris japonicus. In the most extreme and rare case, a burrow, apparently large enough as described earlier, is sighted nestling at least two snapping shrimps, two Amblyeleotris japonicus and two Vireosa hanae.

It is not at all certain that these inhabitants of a burrow are sexually paired in each species, since the collection of an entire association of a burrow has not been possible. Only once in a very fortunate chance in the summer of 1967, a pair of snapping shrimps emerging out from a burrow were discerned to be represented by one berried and one non-ovigerous individual, the latter of which may not necessarily be male. General features of their occurrence in winter are not much different from those in summer months described above, except during the cold hit in January 1968 when, according to Mr. Ch. ARAGa, few snapping shrimps and gobioid fishes were observed on the bottom, suggesting that they were staying in burrows. The partnership between Alpheus bellulus and gobioid fishes is assumingly not associated with seasonal activities.

Measurements of specimens of Alpheus bellulus and Amblyeleotris japonicus so far 
collected underwater from burrows are presented in Table 1.

Table 1. Measurements of specimens collected. Carapace and body lengths of the snapping shrimp are measured from the tip of the rostrum.

Alpheus bellulus MiYa and Miyake

\begin{tabular}{|c|c|c|c|c|c|c|}
\hline Date & Locality & Sex & $\begin{array}{c}\text { Carapace } \\
\text { length } \\
(\mathrm{mm})\end{array}$ & $\begin{array}{c}\text { Body } \\
\text { length } \\
\text { (mm) }\end{array}$ & $\begin{array}{l}\text { Body } \\
\text { weight } \\
\text { (gr) }\end{array}$ & Notes \\
\hline 8 August, 1967 & Ezura & o & 13.2 & 36.9 & 1.7 & $\begin{array}{l}\text { Rendered for identification by } \\
\text { Mr. Y. MrYA }\end{array}$ \\
\hline 9 August, 1967 & Rinkai & 우 & 17.2 & 47.2 & 3.2 & $\begin{array}{l}\text { In berry; rendered for identifica- } \\
\text { tion by Mr. Y. MrYA }\end{array}$ \\
\hline$"$ & $"$ & $\sigma^{7}$ & $11.0+$ & - & - & $\begin{array}{l}\text { Damaged in thorax; rendered } \\
\text { for identification by } \mathrm{Mr} \text {. Y. } \\
\text { MryA }\end{array}$ \\
\hline 29 August, 1967 & Ezura & 우 & 17.1 & - & - & $\begin{array}{l}\text { Damaged in abdomen; in berry; } \\
\text { rendered for food examination }\end{array}$ \\
\hline 2 September, 1967 & Ezura & 우 & 16.6 & 43.2 & 2.0 & $\begin{array}{l}\text { In berry; rendered for food } \\
\text { examination }\end{array}$ \\
\hline 5 August, 1968 & Ezura & o & 15.1 & 44.1 & $1.5+$ & $\begin{array}{l}\text { Cheliped lost; rendered for aqua- } \\
\text { rium observation }\end{array}$ \\
\hline 22 August, 1968 & Rinkai & 우 & 14.4 & 39.6 & 1.2 & $\begin{array}{l}\text { In berry; rendered for aquarium } \\
\text { observation }\end{array}$ \\
\hline$"$ & $"$ & 우 & 15.3 & 42.2 & $1.6+$ & $\begin{array}{l}\text { Cheliped lost; in berry; rendered } \\
\text { for aquarium observation }\end{array}$ \\
\hline
\end{tabular}

Amblyeleotris japonicus TAKaGI

\begin{tabular}{|c|c|c|c|c|c|c|}
\hline Date & Locality & $\begin{array}{l}\text { Body } \\
\text { length } \\
(\mathrm{mm})\end{array}$ & $\begin{array}{l}\text { Total } \\
\text { length } \\
\text { (mm) }\end{array}$ & $\begin{array}{l}\text { Body } \\
\text { height } \\
(\mathrm{mm})\end{array}$ & $\begin{array}{l}\text { Body } \\
\text { weight } \\
\text { (gr) }\end{array}$ & Notes \\
\hline 5 August, 1968 & Ezura & 75.8 & 108.7 & 13.2 & 4.5 & \\
\hline$"$ & , & 72.0 & 100.7 & 12.5 & 4.0 & \\
\hline$"$ & " & 70.2 & 99.1 & 12.5 & 4.1 & \\
\hline$"$ & $"$ & 63.2 & 87.0 & 10.6 & 2.5 & \\
\hline$"$ & $"$ & 79.0 & 117.0 & 12.9 & 5.2 & $\begin{array}{l}\text { Rendered for aquarium observa- } \\
\text { tion and measured on } 10 \text { Sept- } \\
\text { ember }\end{array}$ \\
\hline 19 August, 1968 & Ezura & 75.6 & 105.0 & 13.1 & 6.7 & Rendered for food examination \\
\hline 20 August, 1968 & Rinkai & 61.8 & 87.0 & 10.7 & 3.5 & Rendered for food examination \\
\hline 22 August, 1968 & Rinkai & 63.9 & 88.3 & 10.8 & 3.3 & Rendered for food examination \\
\hline
\end{tabular}

\section{Burrowing Behaviour}

When a captive snapping shrimp is placed in an aquarium with the bottom of a mixture of fine sand, gravel, coral fragments and stones, it immediately starts burrowing. It appears that the snapping shrimp does not first discriminate the nature of bottom surface for hurried burrowing, but then selectively confines its activity to corners of the aquarium or to bases of stones. In all cases repeatedly observed on three individuals, successful burrowing is finally accomplished by leading its burrow beneath stones and corals. It has also frequently been noticed that shells and coral fragments 
scattered on the surface are gathered around the entrance or are even secured into the burrow during night apparently to reinforce the burrow.

On burrowing the snapping shrimp first uses the third and fourth pairs of pereiopods, and often third maxillipeds as well, to loosen the bottom and draw the sand backward, the large chelipeds of the first pair of pereiopods being held forwardly or sometime wedged into the substratum to prevent the burrow from collapsing. The pleopods are effectively employed to fan and shift the fine sand backward out of the burrow. Streaming of turbid water out of the burrow has been frequently observed underwater and this must be the current originated in this way by the snapping shrimp.

Within ten minutes or so the burrow is extended beneath hard objects for about $10 \mathrm{~cm}$, long enough to shelter a shrimp in, where it makes a space in which it can manage to turn. The sand excavated further and heaped up on the floor of the burrow in the manner described above is ploughed and loaded on flattened chelae and is pushed forth outside the burrow. The whole burrowing behaviour is generally similar to that of Callianassa exquisitely described by MAcGinitie and MacGinitie (1949, p. 286). The tunnel thus built further deep into the substratum is generally large enough to nestle gobioid fishes and for the snapping shrimp itself to turn around. The shrimp may dig branches of the tunnel at places when it comes across obstacles, and may open a new entrance by extending one of them.

Gravels and coral fragments are often seized with the smaller chela, never with the snapping hand, of the first pair of pereiopods and stuffed in cavities and crevices of the burrow, aided with the latter, with such elaboration and patience of the architects. Plasticity is, however, attributable to the employment of these chelipeds in this activity, since individuals that have accidentally lost one of the first pair of pereiopods have been observed handling these materials by the use of either the smaller or the snapping hand left on the body without apparent difficulty. Finely articulated and flexible second pair of pereiopods are exclusively used for touching and feeling the objects, as well as for cleaning the body surface. The fifth pereiopods, the sole pair usually directing backward, serve to press the body forth.

The gobioid fish, Amblyeleotris japonicus, has proved itself of its inability to burrow in an aquarium. Left in an aquarium in the absence of the snapping shrimp for a week, the fish has only been able to make a depression on the bottom around its body by splashing the sand around, in which it stays half buried. It is evident from this fact that the burrow is constructed and maintained by Alpheus bellulus and Amblyeleotris japonicus is merely lodging in it.

\section{Interspecific Relationships}

On the sea bottom, Amblyeleotris japonicus staying near the entrance and Alpheus bellulus emerging from the burrow with a load of sand to dump outside have been very commonly seen, when the observer is keeping some distance away from them. 
Both animals are alert outside the burrow and quickly respond by retreating, the snapping shrimp backward and the gobioid fish head first, to any unusual situation, for instance divers and fishes nearing to them or shock of hitting the bottom in the vicinity. In an aquarium, too, they showed similar behaviours when they were accustomed to the new conditions after they had been reared for a month or so.

When the observer approaches to them very gently, the fish withdraws backward inch by inch to the entrance and finally takes the posture of its tail inserted into the burrow. In this state the shrimp can not step out as the fish plugs the entrance, as stated by Herald (1961, p. 235). If the shrimp tries to force out, where its antennae make the appearance from the burrow swinging alongside the tail of the fish, the fish readily exhibits quivering of its tail vigorously and the shrimp disappears deep inside the burrow as if it were warned of danger.

The interaction in this manner between these two species occurs without exception at the entrance and appears to be a means of interspecific transmission of information. It is moreover worth noting that quivering its tail is also seen when the gobioid fish is resting on the bottom apart from the entrance. It is realized presently underwater that the snapping shrimp never goes beyond the fish, unless the fish stays totally away from the way of the shrimp, that however is a very rare case. Whenever the shrimp reaches the fish, the latter instantaneously makes its tail sway restlessly, and, instead of swimming away, remains there. The shrimp then gives up to go further and dumps its load of sand at this spot, resulting the situation which accords with that noticed by LuTher (1958) when he writes: "Der Krebs scheint ihn (den Fisch) kaum zu beachten und schafft seinen Sand unbedümmert unter und neben dem Fisch die Halde hinauf." Evidently the distance of travel of the shrimp from the entrance is diminished as the fish withdraws. In case when there are two shrimps and two fishes dwelling together, the interaction occurs between the shrimp going further out and the fish resting nearer to the entrance. Consequently, if one of the fishes dives into the burrow, leaving another one on the bottom apart from the burrow, the shrimps never come out.

By closer underwater observation, it is evidently revealed that the action of the gobioid fish is not performed intentionally as a favour from the fish itself. Although the fish flickers its tail at times slightly to keep its posture and position on the bottom, it is clearly noticed that the fish quivers its tail vigorously only when the shrimp touches it with its antennae. This quivering is practically nothing to do with maintaining its posture, since the fish is keeping its position fast still all along. The shrimp, on the other hand, behave as if it discriminates the object by feeling with its antennae and, in a moment, recedes into the burrow promptly in response to the movement of the fish.

Behaviours and interactions of these two species are analysed experimentally in an aquarium. When a snapping shrimp alone is placed in an aquarium, it emerges from the burrow it has built and pushes the sand off over a distance of about its size 
from the entrance. It has never been seen travelling further at least during daytime. If, at this stage, a gobioid fish is introduced to approach and stay within reach of the antennae, the shrimp feels the fish for sometime and then, presumably knowing what is there, it starts to unload the sand further away and even on the roof of the entrance. If, however, the fish dives into the burrow and remains there, the shrimp becomes very reluctant in stepping out. Indeed, this lasts over most of daytime, since the fish is nervous and does not react properly in an aquarium. The shrimp feels the fish inside the tunnel and often tries to drive it out in vain as it pushes the sand outside the burrow. In this situation, the shrimp seldom emerges from the burrow and it often occurs that the shrimp dumps the sand just outside or inside the entrance eventually to plug it with this from inside. It is not, however, noticed that they show intimate association on the bottom before the shrimp excavates its burrow, as is recorded by LUTHER (1958).

It is often observed that the snapping shrimp comes in contact with fishes other than Amblyeleotris japonicus, that are kept together in the aquarium. These fishes are for example Chasmichthys dolichognathus, Tripterygion etheostoma and even Abudefduf vaigiensis, that inquisitively visit the burrow. The shrimp is seen reacting to them in two ways. The shrimp may snap to them with its body half exposed from the entrance, followed by quick retire into the burrow. This does not however stun fishes, as described by MacGinitie and MacGinitie (1949) for Alpheus californiensis and A. dentipes. On the other hand, the shrimp may feel fishes with its antennae, as it does to $\mathrm{Am}$ blyeleotris japonicus, and receives always a response of their suddenly swimming away, that in turn stimulates the snapping shrimp itself to retire into the burrow.

As to the roles of the partner animals, HERALD (1961) gives an account for gobioid fishes of genus Smilogobius and associated snapping shrimps as follows: "The shrimp maintain the burrow,... and the gobies, usually a pair, stand guard, like sentinels, at the entrance." Observations of Luther (1958) and MACNAE and KALK (1962) accord generally with this. In fact, it is also commonly observed underwater that Amblyeleotris japonicus exhibit quick withdrawal into burrows, thereby Alpheus bellulus are secured in them without fail, when fishes such as Fugu pardale, Gierres oyena and Pagrus major, that are foraging over the bottom and gather immediately where the bottom sand is dug up, approach their burrows within a half metre or so. It is also not the rare case that Amblyeleotris japonicus show aggressive behaviour- plunge from the head into the substratum, take a mouthful of sand and puff it out from gill openings, accompanied by impetuous twists of their bodies- to Pagrus major and successfully chace them away. In view of the observations mentioned so far, it can rightly be assumed that Amblyeleotris japonicus detects and reacts to the surrounding situations and its presence and behaviours, elicited through interactions with the partner species, are accepted as informations by Alpheus bellulus, the most probable interpretations being that the site of the fish indicates the safty range and quivering movement means danger of going further away. 


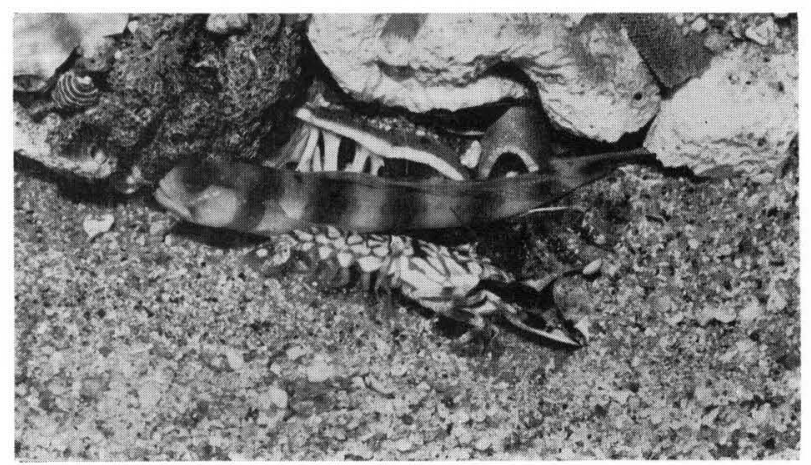

Fig. 5. The shrimp extending the tunnel in an aquarium. Fine sand is fanned backward.

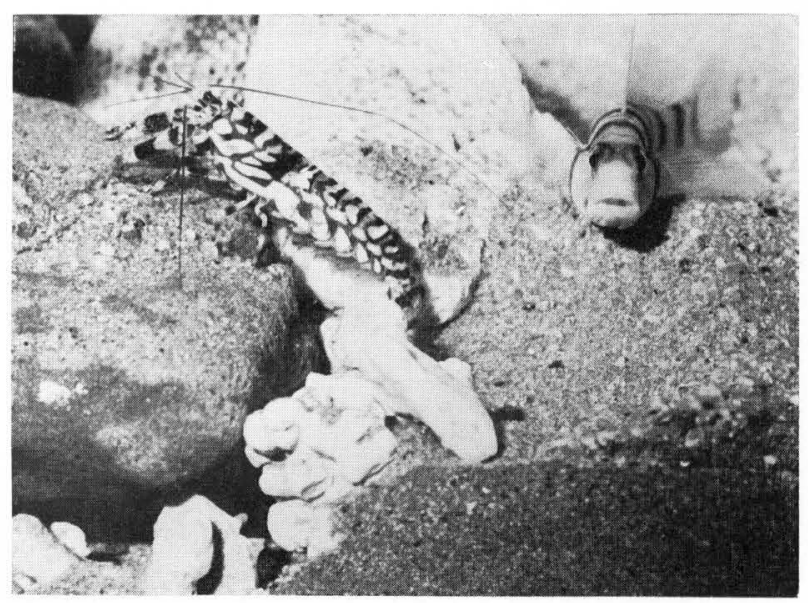

Fig. 6. After the shrimp feels the fish staying on the bottom, it comes out further and freely from the burrow.

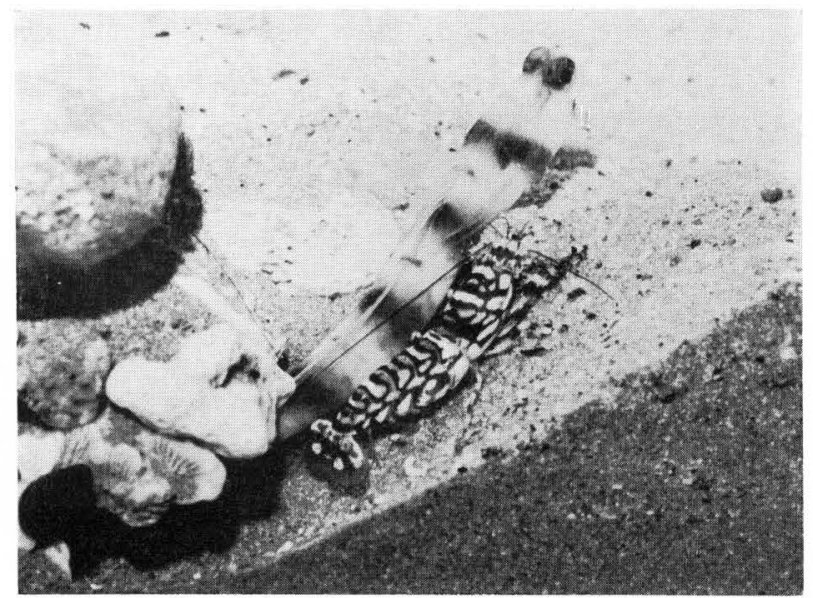

Fig. 7. When the fish takes its position at the entrance, the shrimp dumps a load of sand at the side of the fish. 


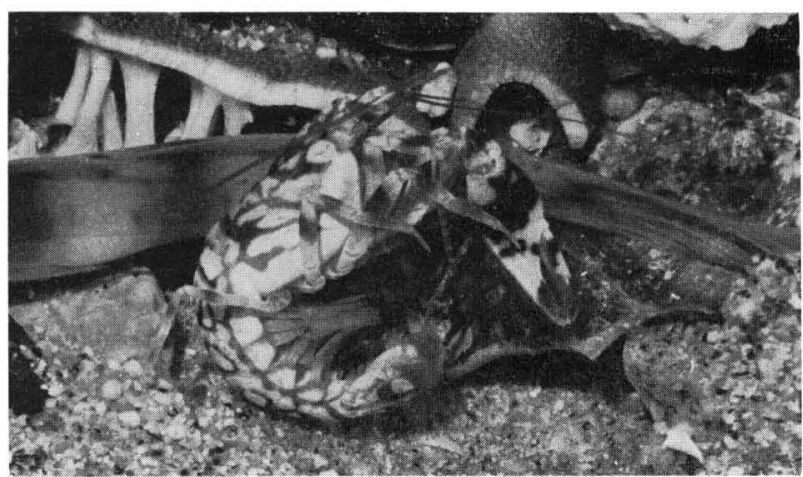

Fig. 8. The shrimp turns round inside the burrow by bending its abdomen and twisting its body.

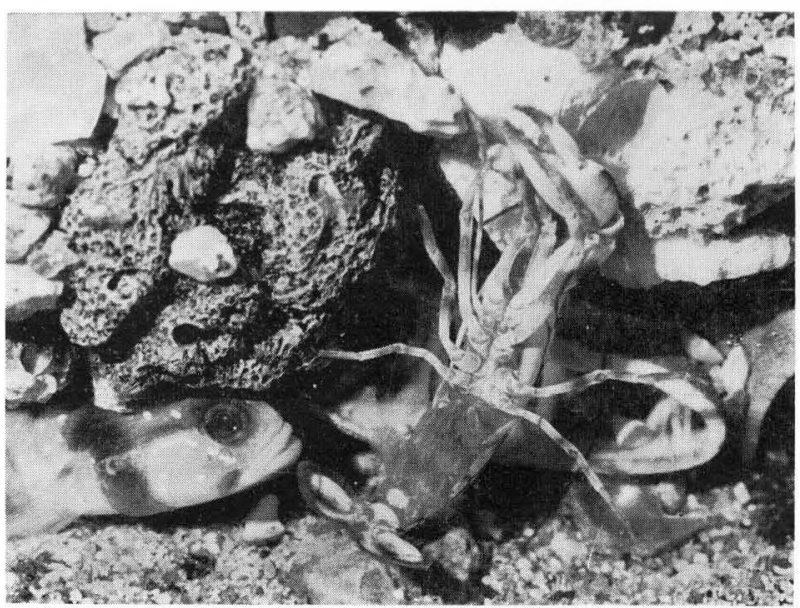

Fig. 9. The shrimp lost its snapping hand manages to stuff a gravel into a crevice with the aid of other pereiopods.

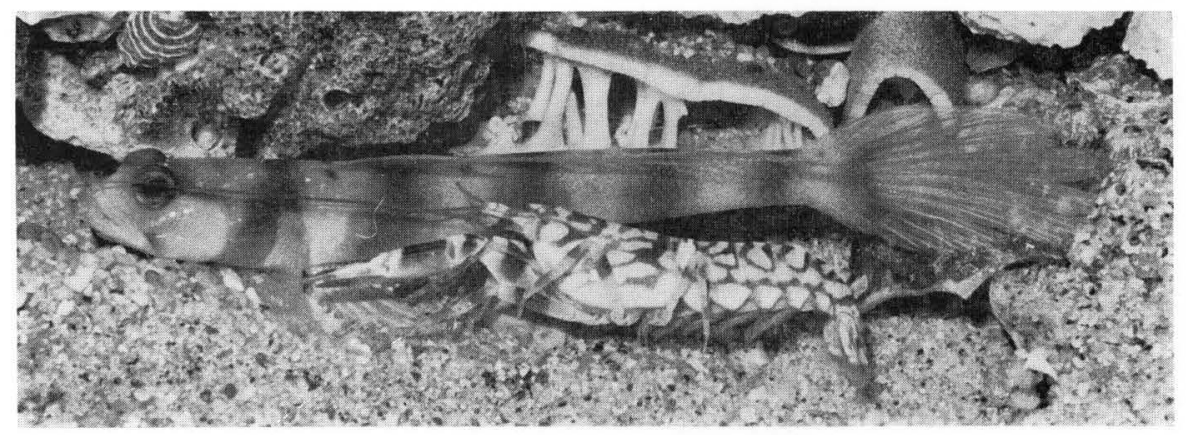

Fig. 10. When the fish is persistently staying inside the burrow, the shrimp often tries to push it out with its antennae and chelae. 
Because of the scarcity of observations and lack of specimens, it is impossible to give detailed accounts and analyses of interrelations between the snapping shrimp and other gobioid fishes than Amblyeleotris japonicus. It appears however, though it has to be proved, that another unidentified gobioid fish is playing similar role to that of Amblyeleotris japonicus. On the contrary, Vireosa hanae is not in close contact with the snapping shrimp and is simply utilizing the burrow of the latter for hiding. It is the frequent case that Vireosa hanae dive down into the burrow first, subsequently causing the quick withdrawal of the snapping shrimp and last of all of Amblyeleotris japonicus. This is not unexpected because, differing from Amblyeleotris japonicus, Vireosa hanae are hovering above the bottom and may be able to reach burrows without encountering with snapping shrimps outside burrows.

The interspecific relationship of Alpheus bellulus and Amblyeleotris japonicus seems essentially to be associated with sharing the space of burrow and not much to be related to food or other requisites. Herald (1961) has suggested as follows: "That the relationship is not completely idyllic is shown by the fact that baby snapping shrimps have been found in the stomachs of the gobies." Even if this is occurring in the present case, however, it may not be appropriate to put too much importance on this as a characteristic of the relationship, because the breeding season of the snapping shrimp is evidently limited, while their relationship is maintained throughout a year. Examination of

Table 2. Stomach and intestinal contents of Alpheus bellulus and Amblyeleotris japonicus.

\begin{tabular}{|c|c|c|c|c|c|}
\hline \multirow{2}{*}{$\begin{array}{l}\text { Species } \\
\text { Date }\end{array}$} & \multicolumn{2}{|c|}{ Alpheus bellulus } & \multicolumn{3}{|c|}{ Amblyeleotris japonicus } \\
\hline & $\begin{array}{l}29 \text { August, } \\
1967\end{array}$ & $\begin{array}{c}2 \text { September } \\
1967\end{array}$ & $\begin{array}{l}19 \text { August, } \\
1968\end{array}$ & $\begin{array}{l}20 \text { August, } \\
1968\end{array}$ & $\begin{array}{l}22 \text { August, } \\
1968\end{array}$ \\
\hline Locality & Ezura & Ezura & Ezura & Rinkai & Rinkai \\
\hline Carapace/Body length (mm) & 17.1 & 16.6 & 75.6 & 61.8 & 63.9 \\
\hline Body weight (gr) & - & 2.0 & 6.7 & 3.5 & 3.3 \\
\hline Gut content weight (mg) & 25 & 45 & 50 & 30 & 70 \\
\hline \multicolumn{6}{|l|}{ Food items: } \\
\hline Anomurans & - & - & 1 & - & - \\
\hline Corophiid amphipods & - & - & 17 & 3 & 21 \\
\hline Other amphipods & - & 1 & - & - & - \\
\hline Tanaidaceans & - & - & - & 6 & - \\
\hline Harpacticoid copepods & 1 & - & 2 & 6 & - \\
\hline Calanoid copepods & 1 & - & - & - & - \\
\hline Ostracods & - & - & - & - & 2 \\
\hline Gastropods & 1 & 1 & 3 & - & 1 \\
\hline Nematodes & 2 & 1 & - & - & - \\
\hline Forminiferans & - & - & 1 & 一 & 2 \\
\hline Organic remains & plenty & plenty & medium & scarce & medium \\
\hline
\end{tabular}


stomach and intestinal contents of Amblyeleotris japonicus shows that digestive tracts, simply S-shaped, are full of sand grains and tiny shells over the whole length. This is expected from their behaviour that, while they are posting on the bottom, they often engulf surface sand in a manner shown in threatening enemy fishes. At the same time, these rough contents remind me of the nests of corophiid amphipods recently found underwater on the course of the present study. This corophiid amphipod has overwhelming population on the shallow sandy bottom and creeps actively carrying its nests made of sand grains and shells. Closer examination of the gut contents, presented in Table 2, makes it manifest that even in the breeding season of the snapping shrimp the major food organisms are these amphipods and also that sand grains and shells are not accidentally ingested. Food of Alpheus bellulus is assumed to be small animals of epi- and interstitial faunae of sandy bottom and detritus, as the stomach contents are made up of a fairly large amount of unidentifiable remains. No such materials as to suggest that the shrimp is rationed food directly by the gobioid fish have been detected. On the other hand, no evidence has been obtained that would either support or deny indirect connections between these animals that, for instance, the shrimp is feeding on faeces of the gobioid fish or the corophiid amphipods serving as main food for the gobioid fish are cultured specially abundantly around the burrow with decaying organic materials among the sand excavated by the shrimp.

\section{Evolution of Interspecific Relationship}

As has been mentioned earlier, it appears as if Amblyeleotris japonicus is actively warning Alpheus bellulus of danger by swaying its tail. This kind of behaviour has not been known in other partnerships. To consider what situation and process have contributed in establishing this particular kind of interspecific relationship and communicative hebaviour needs of course a great deal of analytical evidences as well as field observations; nevertheless, it may be worthwhile to postulate a hypothesis at stages of accumulation of evidence.

Among the fish groups the suborder Gobiina is one of the major groups in which a variety of species have acquired habit of dwelling in the burrow, particularly together with other animals. Some of the cases of snapping shrimp sharing the burrow with gobioid fish have already been referred to. Apart from these, MaGnAe (1957) has recorded an association between Alpheus crassimanus and Gobius nudiceps from mudflats of Port Elizabeth, South Africa. In addition, MAcnaE and KALK (1962) have also listed partnerships between snapping shrimp and gobioid fish in Moçambique water, in which included are Alpheus rapax and $A$. rapacida with Gipptocentrus octofasciatus and Gobius delagoae in the lower midlittoral and infralittoral fringe, and Alpheus malabaricus with Butis butis on soft mudflats.

In his study of the Japanese gobioid fish, TAKaGr (1966) has made a survey on ecological types in the group and presents the following genera as having members 'commensal' with the common snapping shrimp, Alpheus brevicristatus, in the latter's 
burrow: Acentrogobius (exp. A. pflaumi=Gobius pflaumi, A. koumansi), Vireosa, Lotilia, Ctenogobiopsis and Apocryptodon. He also lists gobioid genera, members of which are utilizing the burrow of other animals such as ghost shrimp, crab, polychaete and other gobioid fish, that are Typhlogobius, Eutaeniichthys, Acanthogobius (=Synechogobius), Chaenogobius, Paleatogobius and Apocryptodon. On the contrary, Eutaeniichthys gilli, Acanthogobius flavimanus, Boleophthalmus pectinirostris (=B. chinensis), and Eleotriodes helsdingeni) are assigned the ability to burrow. He regards burrowing habit as the advanced form of diving into the substratum and burying itself for escape. It is obvious that the habit of inhabiting the burrow, of own or of others and throughout life or temporarily, is prevalent among the gobioid fish, both the family Eleotridae and the family Gobiidae, if it is not of the majority.

Burrowing habit is also common in the snapping shrimp. Besides those cited already that are sharing the burrow with gobioid fishes, various species have been also noticed by many authors: for example, Alpheus rapax FABRICIUS (non A. rapax DE HAAN $=A$. distinguendus DE MAN) and $A$. platyunguiculatus by BANNER (1953), A. heterochaelis and $A$. normanni by Williams (1965), and $A$. brevicristatus and $A$. rapax by MiYa (personal communication; in the Amami Islands). Moreover, habit of living in holes and crevices of rocks and among shells is widespread in the snapping shrimp, as well as in the gobioid fish.

It may not be an inappropriate supposition that both Amblyeleotris japonicus and Alpheus bellulus, as a member of the groups mentioned above respectively, would have acquired or would have been developing burrowing habit on the similar habitat in the identical geographic range, and would have held similarities in the mode of life to each other. This can be regarded as an essential prerequisite for an intimate interrelationship. As is supposed from their present food preferences, they would not have come in predator-prey relationship, nor in critical competition for food as to exclude the other. On the other hand, instead of exploiting the habitat, that is usually most likely to occur in sessile organisms, they might have compromised their demands for space through segregated utilization. Considering from the morphology of these animals, the snapping shrimp must have attained excellence in burrowing and, as most lower animals are so, is more rigid in modifying the habits. The circumstances have possibly given rise to a chance on the gobioid fish to utilize the burrow of the snapping shrimp for housing, retaining largely its original mode of life, as long as the former does not obtrusively restrict the activities of the latter, thereby it has dropped off or has abandoned to develop burrowing habit of its own. Since there are no other animals in the very habitat that maintain burrowing life so beautifully as Alpheus bellulus, the association must have been only successfully established between these particular species.

During the course of development of their lives of dwelling together in the burrow, they must inevitably fall in physical contact with each other. Supposedly, the snapping shrimp feels the gobioid fish with its antennae, as it usually does to any aline 
objects. With this physical stimulus, instead of freeing from the snapping shrimp as most fishes of different mode of life may do, the gobioid fish sticks to the particular habitat and simply exerts a somatic response of shaking the feelers off with its tail. This in turn acts to hamper the way of the snapping shrimp. Frequent exchanges of this set of unconditional responses may function as learning at interspecific level. KLOPFER (1962) has emphasized "to distinguish, however, between communication of inter- or intraspecific levels, for there are differences in the communicative processes and the problems existing at these two levels," and has discussed the possibility of the conditional stimulus taking on the meaning of the unconditional response on the intraspecific level. For the interspecific level, however, he focusses his interest on the problem of discrimination of inter- and intraspecific signals. While most of behaviours presently occurring on interaction between the snapping shrimp and the gobioid fish have obviously retained substantial functions, there are also some that have taken on the specialized meanings. The direct interaction occurs naturally most frequently when the gobioid fish recognizes danger and is posting near the entrance of the burrow. To the snapping shrimp which can not realize the situation outside the burrow well, the presence and responses of the gobioid fish have been associated with unfavourable situation and are understood as signs of danger and extent of safety area.

In the case of Vireosa hanae with Alpheus bellulus, their modes of life differ much from each other. They come in physical contact only when the fish perceives danger and dives into the burrow for hiding indifferently to the snapping shrimp and the latter is incidentally warned to withdraw. However, any further development of a signal system would have been hardly possible for lack of constant, continued contact and under the co-existence of Amblyeleotris japonicus, if the snapping shrimp had not been watching the fish hovering above to learn the situation. This and that similarities have been noticed in the behaviour between the unidentified gobioid fish and Amblyeleotris japonicus would insinuate that the particular interrelation is specific rather to the mode of life of animals taking in part, regardless of the species.

The interspecific relationships between the snapping shrimp and gobioid fishes have of course much to be elucidated and the processes of their establishment may be debatable. If they had evolved during the geological periods, phylogenic and palaeogeographical backgrounds should also be taken into consideration for full understanding. Whether the association is taken up in their younger stages or is established during the adult life, an important clue for functional understanding, is not known, since no collection of the youngs or the larvae of these animals has ever been successful.

\section{Terms of Interspecific Relationship}

Most of the gobioid fishes sharing the burrow with snapping shrimps are customarily noted as "burrow commensals". MAcGinitie and MAcGinitie (1947), for example, assign the interrelationship of snapping shrimp and gobioid fish to commensalism among three categories of symbiosis, commensalism and parasitism. TAKAGI 
(1966) recognizes for the Japanese gobioid fish nine ecological types and assigns those sharing the burrow with snapping shrimp to the commensal type, while he includes apparently unduly those utilizing the burrows of other animals 'parasitically' into the burrowing type. MACNAE and KALK (1962) mention the interrelations as partnership generally, but in part denote the gobioid fish as commensal with the snapping shrimp. Herald (1961), on the contrary, regards his example as symbiotic relationship. Luther (1958) also uses the term "Symbiose" to his case and describes: "Der wechselseitige Vorteil dieses Zusammenlebens ist offenbar: der Fisch braucht sich keine Wohnhöhle zu graben; dafür warnt er den Krebs vor Raubfischen." LutheR's case is, however, confusingly referred to under "commensals which feed on host associated material" by PAtTon (1965).

As it has been pointed out recently by MATTHEs (1967), commensalism has been diversely used and has meant various kinds of interrelationship. AlleE et al. (1949) and HENRY (1966) have reverted to the broad meaning of symbiosis originally used by DE BARY (1879) to denote the constant intimate relationship of living together between dissimilar species, in which "the phenomena of commensalism, in which the benefit relation is one-sided, without injury to the host, and parasitism, in which the relation is typically detrimental to the host (Steinhous, 1946)" are included. According to AlLEE et al., on the other hand, differing "considerably from the simplest implications of being messmates," the concept of commensalism should be "expanded to include all those ecological unions in which, although both parties do not benefit, as in mutualism, neither one is harmed, as in parasitism, by the association. Space, substrate, shelter, and transport relations may be involved, as well as food," that is not however followed up by HENRY (1966). ODUm (1954) reduces interactions between two species, on the basis of effect of the interaction on their population growth, to neutralism, competition, mutualism, commensalism, amensalism, parasitism and predation. Contrary to these, for instance, Nicol (1960) sees much in external relationship between two species for commensalism and emphasizes "a close physiological association between two species, often for mutual benefit" for symbiosis. Paramount emphasis is seemingly put on the food and nutrients aspects in the analysis of interspecific relationships between fishes by NIKOLSKy (1963), who distinguishes various nature of interspecific relationship of predation, parasitism, commensalism, antagonistic interrelations for same food for nutrition and many other types, and recognizes commensalism as " $a$ form of interrelations between animals that are beneficial to one side and indifferent to the other." ') SchwerdTfEger (1963) attaches a more literal meaning to the concept of commensalism and limits it to imply the relations of partner organisms, that, "Wenn sich ein Tier einem oder einigen andern zugesellt, verfolgt es gelegentlich das Ziel, seinen Nahrungserwerb zu erleichtern, indem es sich sozusagen an einen fremden Tisch setzt," whereas he discriminates symbiosis as "eine hetero-

2) “Форма взаимоостнопений между животными, полезных идя одной стороны и безразаичных для другой” (р. 112). 
typische Relation, bei der beide Partner aufeinander angewiesen sind und eine zeitweilige oder dauernde räumliche Verbindung eingehen. Sie unterscheidet sich vom Mutualismus durch die stärkere Abhängigkeit der Partner voneinander und das obligatorische räumliche Zusammensein." NAumov (1963) is of opinion that commensalism and mutualism are concerned primarily with food and nutritional aspects of relations within symbiosis, and recognizes three categories of interrelationship on the basis of food and spacial relations: sozhitelstvo ${ }^{3)}$ (symbiosis), nesovmestimosti ${ }^{4}$ ) (antibiosis) and bezrazlichnaja terpimosti ${ }^{5}$ (neutralism). These categories are not corresponding to the three main types of symbiosis - parasitism, commensalism and mutualism - given by ALLEe et al. (1949). Following largely the definitions provided by Schwerdtfeger (1963), Matthes (1967) assigns the interspecific relationships into three primary categories of "Parasitismus", "Karpose" and "Symbiose", stressing that commensalism should be put aside of the system of category as it means that "Ein Tier nimmt an der Mahlzeit eines anderen Tieres teil."

It is not the intention of the present paper to advance the discussion on terminology concerning interspecific relationship, but just to make clear the concepts of terms which are to be used. Diverse usage and differences in meaning of these terms are apparent and, by rough comparison of terminologies proposed, are considered to have arisen principally from equivocal insinuation of commensalism and varying importance attached to the benefit relation in relation to the spacial relation in a system of concept. Indeed, the benefit relation has naturally a fundamental concern in the nature of the interspecific relationship and nevertheless we can never be sure of this until detailed evidences are presented to prove it, say, not the fact that gobioid fishes happen to be

- excavated from burrows of snapping shrimp on estuary mudflats, but the evidence that, for instance, gobioid fishes escape danger by diving into burrows of snapping shrimp or they are shared rations by the latter on the bottom when tide is up.

It follows always after the finding of co-existence of two species that their situations in the interrelationship are elucidated. In this connexion, it seems to be appropriate to discriminate terms to indicate spacial relation, just "Zusammenleben" for example, for convenience of description and for avoidance of confusion in terminology. Commensalism, at the same time, should be strictly used to the case where the partner species are associated through sharing food, usually with one-sided benefit, as supported by many authors. In view of these arguments, it is evident that the partnership of Alpheus bellulus and Amblyeleotris japonicus is by no means commensalism, and falls in a category of "Symbiose- Zoosymbiose- die übrigen Zoosymbiosen" of Matthes' system (1967).

\section{Summary}

1. Underwater and aquarium observations and examination of specimens have been made to clarify habitats, behaviours and associated lives of Alpheus bellulus
3) сожитедьство
4) несовместнмость
5) безраздичная тершимость 
Miya and Mryake with Amblyeleotris japonicus TAKagr, as well as with Vireosa hanae Jordan et Starks.

2. Alpheus bellulus, a burrowing snapping shrimp, is found to have abundant population on the sandy bottom at depths of 2 to 7 metres in fringing waters of reefs of Tanabe Bay. It constructs the burrow invariably by making use of stones and coral fragments buried in the substratum. In almost all cases, Amblyeleotris japonicus is found dwelling together in the burrow of Alpheus bellulus, and Vireosa hanae is often associated in addition.

3. Alpheus bellulus usually comes out of the burrow with a load of sand and Amblyeleotris japonicus is posting on the bottom near the entrance, while Vireosa hanae is hovering about a half metre above the bottom. On approach of a diver, it has been noticed that Amblyeleotris japonicus recedes to the entrance, thereby impeding the activity of Alpheus bellulus by swaying its tail in response to touch of the antennae. Observations in an aquarium have confirmed that, when Amblyeleotris japonicus is lying inside the burrow, Alpheus bellulus very seldom emerges from the burrow. The presence and action of Amblyeleotris japonicus appears to impart conditional meanings of the extent of safety area and not going further out to Alpheus bellulus.

4. From the analysis of their gut contents, it is suggested that Alpheus bellulus and Amblyeleotris japonicus are not in predator-prey relation nor are they sharing food, denying commensalism between them.

5. On the basis of all these evidences in combination with knowledges reported by others, the possible process of establishment of their interspecific association and signal system is discussed, and concepts of terms pertaining to interspecific relationship are also briefly considered.

\section{REFERENCES}

Allee, W.C., Emerson, A.E., Park, O., Park, T. and Schmidt, K.P. 1949. Principles of Animal Ecology. Saunders, Philadelphia. 837 pp.

Araga, Ch. and Tanase, H. 1968. Further record of winter fish stranding in the vicinity of Seto. Publ. Seto Mar. Biol. Lab., Vol. 16, No. 3, pp. 207-218.

Banner, A.H. 1953. The Crangonidae, or snapping shrimp, of Hawaii. Pacific Sci., Vol. 7, No. 1, pp. 3-144.

Henry, S.M. (ed.) 1966. Symbiosis. Vol. 1. Academic Press, New York. 478 pp.

Herald, E.S. 1961. Living Fishes of the World. Hamilton, London. 304 pp.

KLopfer, P.H. 1962. Behavioral Aspects of Ecology. Prentice-Hall, New Jersey. 173 pp.

Luther, W. 1958. Symbiose von Fischen (Gobiidae) mit einem Krebs (Alpheus djiboulensis) im Roten Meer. Z. f. Tierpsychol., Vol. 15, No. 2, pp. 175-177.

MacGinitie, G.E. and MAcGinitie, Nettie. 1949. Natural History of Marine Animals. McGraw-Hill, New York. 473 pp.

MACNAE, W. 1957. The ecology of the plants and animals in the intertidal regions of the Zwartkops estuary near Port Elizabeth, S. Africa. Parts I and II. J. Ecol., Vol. 45, No. 1, pp. 113-131. Pls. 5-7; No. 2, pp. 361-387.

MACNAE, W. and KALK, Margaret. 1962. The fauna and flora of sand flats at Inhaca Island, Moçambique. J. Anim. Ecol., Vol. 31, No. 1, pp. 93-128. 
Matthes, D. 1967. Die Terminologie interspezifischer (heterotypischer) Beziehungen. Zool. Anz., Vol. 179, Nos. 5/6, pp. 313-319.

Mrya, Y. and Mryake, S. 1969. Description of Alpheus bellulus sp. nov. associated with gobies from Japan (Crustacea, Decapoda, Alpheidae). Publ. Seto Mar. Biol. Lab., Vol. 16, No. 5, pp. 307314.

Naumov, N.P. (Наумов, Н.II.) 1963. Экология Животных. Изд. Внспая шкода, Mоsсоw. 618 рp. Nicol, J.A.C. 1960. The Biology of Marine Animals. Pitman, London. 707 pp.

Niкоцsкy, G.V. (Никодьский, Г.В.) 1963. Экология Рыб. Изд. Высшая пкола, Moscow. 368 pp.

Odum, E.P. 1954. Fundamentals of Ecology. Saunders, Philadelphia. 384 pp.

Patton, W.K. 1967. Commensal crustacea. Proceedings of the Symposium on Crustacea held at Ernakulam from January 12 to 15, 1965, Part 3, pp. 1228-1243.

Schöne, H. 1961. Complex Behaviour. In: Waterman, T.H. (ed.) "The Physiology of Crustacea", Vol. 2, pp. 465-520. Academic Press, New York.

Schwerdtreger, F. 1963. Oekologie der Tiere. Band I: Autoekologie. Parey, Hamburg. 461 pp.

TAKaGI, K. 1957. Descriptions of some new gobioid fishes of Japan, with a proposition on the sensory line system as a taxonomic character. J. Tokyo Univ. Fish., Vol. 43, No. 1, pp. 97-126, Pls. V-VI.

1966. Distributions and ecology of the gobioid fishes in the Japanese waters. Ibid., Vol. 52, No. 2, pp. 83-127. (in Japanese)

Williams, A.B. 1965. Marine decapod crustaceans of the Carolinas. Fishery Bull., Vol. 65, No. 1, pp. 1-298.

Yonge, C.M. 1949. The Sea Shore. Collins, London. 311 pp. with Pls. I-XXX $+1-40$. 